\title{
Die hard in Lake Bourget! The case of Planktothrix rubescens reborn
}

\author{
Marthe Moiron ${ }^{1,2}$ (D), Frédéric Rimet ${ }^{2}$, Cyrille Girel ${ }^{1,3}$ (D) and Stéphan Jacquet ${ }^{2, *}$ (D) \\ ${ }^{1}$ CISALB, 42 rue du Pré Demaison 73000, Chambéry cx, France \\ ${ }^{2}$ Université Savoie Mont Blanc, INRAE, UMR CARRTEL, 75 bis avenue de Corzent 74200, Thonon les Bains cx, France \\ ${ }^{3}$ Grand Chambéry, 106 allée des Blachères 73026, Chambéry cx, France
}

Received: 10 June 2021; Accepted: 24 August 2021

\begin{abstract}
Blooms of Planktothrix rubescens have been recorded for 15 years in Lake Bourget (France), from 1995 to 2009. Then, the presence of this filamentous and toxic cyanobacterium became anecdotic between 2010 and 2015 and it was thought that its proliferation was over. However, blooms occurred again in 2016 and 2017 despite apparent low phosphorus concentrations in surface waters of the lake. We have attempted to explain the reasons for this come back in order to develop scenarios helpful to stakeholders who are concerned such proliferations may occur in the future. We show that phosphorus input, both from the main tributaries to the lake and possibly from the sediments, were likely the triggers of the new development of the cyanobacterium provided a minimum autumn/winter inoculum of $P$. rubescens was detected the year before. The subsequent bloom was observed deeper than previous years and associated with a conjunction of factors known to favour the development of this species (i.e., mild winter temperature, water column stability, available light at depth, surface water transparency, low predation, etc.). Although many factors and processes could account for the occurrence and bloom of the cyanobacterium, a plausible scenario is proposed. One thing remains unclear: where does this cyanobacterium "hide" when it is not observed during the routine monitoring surveys and from which place it could initiate its development (nearshore, the pelagic zone, or from the sediment?).
\end{abstract}

Keywords: Lake / cyanobacteria / Planktothrix rubescens / bloom / phosphorus / river input / scenario / prediction

\section{Introduction}

Lake Bourget, the largest deep natural lake in France, has undergone eutrophication during the second part of the 20th century, as with many other ecosystems worldwide (Jenny et al., 2020). While the phosphorus concentration was lower than $10 \mu \mathrm{g} / \mathrm{L}$ before 1940 , it reached up to $100 \mu \mathrm{g} / \mathrm{L}$ during the 1980s' because of massive discharges from industrial effluents and insufficiently treated domestic wastewaters (Jacquet et al., 2005). With eutrophication, biological changes within the eukaryotic microbial communities were noted; initially $c a$. 1940 and again between 1960 and 1980 (Capo et al., 2016, 2017). Management actions were set up to reduce nutrient concentrations in the lake, leading to a lower phosphorus concentration which dropped under $20 \mu \mathrm{g} / \mathrm{L}$ after 2000 (Capo et al., 2016, 2017; Jacquet et al., 2017). Significant ecological changes occurred in the pelagic compartments during the lake's reoligotrophication, notably regarding the toxic filamentous cyanobacterium Planktothrix rubescens (Jacquet et al., 2014; Frossard et al., submitted).

\footnotetext{
*Corresponding author: stephan.jacquet@inrae.fr
}

Planktonic cyanobacterial species are characterized by adaptations and tolerances to various environments and can produce important amounts of various toxins. Among these species, P. rubescens (Anagnostidis and Komarek, 1988) is a red-coloured filamentous and gas-vacuolated cyanobacterium, with photo-heterotrophic capabilities, likely to develop in meso- to moderately eutrophic conditions (Zotina et al., 2003; Jacquet et al., 2005; Ernst et al., 2009; Dokulill and Teubner, 2012). It can self-adjust its position in the water column via buoyancy to its preferred low light environment, and maybe in response to other resources, where it often forms deep water maxima in stratified lakes of temperate latitudes (Feuillade, 1994; Micheletti et al., 1998; Bright and Walsby, 2000; Vinçon-Leite et al., 2002; Zotina et al., 2003; Jacquet et al., 2005; Posch et al., 2012). This taxon can be considered an R-strategist according to Reynolds et al. (2002), and is known as an important producer of hepatotoxic microcystins (MCs) (Fastner et al., 1999; Briand et al., 2005) that are harmful to a variety of animals, including humans (Sotton et al., 2011; Sotton et al., 2012; Kurmayer et al., 2015). Indeed, $P$. rubescens produces a variety of microcystins, especially MC-LR and MC-RR, and these toxins have been shown to contaminate different fish tissues. Both filaments and toxins 
have been observed in intestinal tracts of whitefish and the presence of MC-LR has been detected in their intestine and liver. MCs were also detected in the muscles and liver of young perch of the year through dietary routes, particularly via the consumption of MC-containing Daphnia (Sotton et al., 2011, 2012). Consequently, such toxins can be incorporated into different organisms by ingestion of $P$. rubescens filaments, leading to potential adverse effects on the animals' health. The issue is particularly important since Lake Bourget is a place for an important professional and recreational fishing activity and is a source of drinking water for thousands of inhabitants.

While paleolimnological data first revealed the importance of this species in Lake Bourget during the early years of eutrophication (i.e., prior to 1930; Savichtcheva et al., 2015), $P$. rubescens was mainly observed and counted as a dominant species in the lake between the mid-1990s and 2009. This was explained as a response to the reoligotrophication process of this lake, intermediate phosphorus levels, important water column stability, increasing transparency, etc. (Jacquet et al., $2005,2014)$. The success of reoligotrophication was noticed in that, from 2010, the species declined and "disappeared", and, in the same time, phytoplankton biomass was considerably reduced and taxa composition changed to more preferably species (Frossard et al., submitted). However, with increasing phosphorus concentrations in surface waters of the lake, $P$. rubescens "reappeared" and biomasses were recorded in 2016 and 2017.

This study aims at explaining this paradoxical situation (apparent phosphorus depletion and $P$. rubescens reappearance) and proposes scenarios to predict future possible developments of this cyanobacterium in Lake Bourget. Longterm ecological monitoring survey in this lake offers the possibility to analyze factors responsible for the development of cyanobacteria/algal species, therefore we used the dataset available for the lake and of its main tributaries to explain what could have been the reasons of the 2016-2017 bloom episodes of $P$. rubescens. Our hypotheses were that phosphorus input from rivers and/or sediment could be important factors triggering a new development of the cyanobacterium, whose growth and development could be sustained thereafter thanks to a conjunction of favorable conditions. Our results tend to confirm these hypotheses and highlight also the importance of a minimal autumn/winter concentration of the cyanobacterium (referred latter to as an inoculum) to develop further during the year.

\section{Methods}

\subsection{Description of the site}

Lake Bourget $\left(45^{\circ} 44^{\prime} \mathrm{N}, 231 \mathrm{~m}\right.$ altitude) is the largest natural deep lake in France and is located on the edge of the Alps. It is a warm, meromictic and elongated $(18 \mathrm{~km}$ in length and $3 \mathrm{~km}$ for maximal width). It is north-south orientated with an area of $42 \mathrm{~km}^{2}$, a total volume of $3.5 \times 10^{9} \mathrm{~m}^{3}$, maximum and average depths of $145 \mathrm{~m}$ and $80 \mathrm{~m}$ respectively, and a water residence time of approximately 10 years. Mixing from winter turnover reaches the bottom of the lake only during very cold winters. It has a catchment area of about $560 \mathrm{~km}^{2}$, with maximum and average altitudes of 1845 and $700 \mathrm{~m}$ respectively. There are two important cities beside the lake;
Chamberry to the south and Aix-les-Bains to the east, with a combined population of 180,000 inhabitants, plus a large influx of tourists $(>50,000)$ each summer. The lake has suffered from eutrophication since 1950 and water quality restoration programs started in the 1970s. These programs involved the development and improvement of wastewater treatment plants, and in 1981, the diversion of the treated sewage of the two main cities from the lake, directly downstream the lake into the Rhône River. Other improvements of the functioning of the sewer system - especially the control of the combined sewer overflows - lead in the recent years to an additional reduction of the nutrient loading to the lake. Two rivers, the Leysse and the Sierroz, are the main inputs to the lake, with average flow rates of 6.5 and $2.5 \mathrm{~m}^{3} / \mathrm{s}$, respectively. The flow rates of these two rivers can occasionally (during floods for instance) reach more than 120 and $30 \mathrm{~m}^{3} / \mathrm{s}$, respectively. The outflow from the lake, located on its northern shore, is known as the Savière channel (length: $4.5 \mathrm{~km}$, mean flow rate: $10-30 \mathrm{~m}^{3} / \mathrm{s}$, annual output: $0.5 \mathrm{~km}^{3}$ ) and it flows into the Rhone River.

\subsection{Data}

All lake data used in this paper correspond to sampling performed at the reference sampling site located in the middle and deepest part of the lake, referred to as point B and are part of the lake observatory and its information system (Rimet et al., 2020; (C) OLA-IS, AnaEE-France, IRLife, INRAE of Thonon-les-Bains, CISALB). The site is more than $1.5 \mathrm{~km}$ from each bank and more than 5 and $10 \mathrm{~km}$ from the Sierroz and Leysse rivers, respectively. A conductivity-temperature-depth (CTD) measuring device (CTD SEABIRD SBE 19 Seacat profiler) was used to obtain vertical profiles of temperature, dissolved oxygen, $\mathrm{pH}$, and conductivity.

Temperature data were used to determine the onset of water column stratification. We assumed that stratification had occurred when there was a temperature differential of more than $1{ }^{\circ} \mathrm{C}$ between the 2 - and $50-\mathrm{m}$ depths on two consecutive sampling dates. The Brunt-Väisälä frequency (which measures the natural frequency of oscillation of a vertical column of water, and can be viewed as an index of the water column stability, Lemmin, 1978) was also calculated from the temperature values, according to the following equation:

$$
N^{2}=\frac{g}{\rho}\left(\frac{d \rho}{d z}\right)
$$

where $N^{2}$ is the stability coefficient (in s ${ }^{-2}$ ); $g$ is the acceleration parameter (in $\left.\mathrm{m} / \mathrm{s}^{2}\right) ; \rho$ is the water density (no unit); $z$ is the depth (in m); with: $\rho(\mathrm{T})=1000-7 \times 10^{-3}(\mathrm{~T}-4)^{2}$ according to Lemmin (1978) where $T$ is the temperature (in ${ }^{\circ} \mathrm{C}$ ).

Nutrient concentrations (such as total phosphorus and P-PO ${ }_{4}$, but also total nitrogen, $\mathrm{N}-\mathrm{NO}_{3}, \mathrm{~N}-\mathrm{NH}_{4}$ ) were measured monthly to bi-monthly at ten different depths (from surface to bottom) according to normalised procedures and protocols (AFNOR, 2015). Transparency data were obtained using a Secchi disk. The concentration of chlorophyll $a$ was determined using the method of Strickland and Parsons (1972). Phytoplankton species and biovolumes were analysed 
according to the European standardised method (AFNOR, 2006) of Uthermöhl (1958). For both chlorophyll $a$ and phytoplankton determination, samples consisted in an integrated water sample collected between 0 and $20 \mathrm{~m}$ using a dedicated sampler (Pelletier and Orand, 1978). Species biovolumes used for this monitoring are available in Rimet and Druart (2018). For P. rubescens, the cell concentrations were estimated by counting $200-\mu \mathrm{m}$ length filaments and by assuming a mean cell length of $5 \mu \mathrm{m}$. Several vertical profiles of the main phytoplankton groups, including $P$. rubescens, and of the temperature were also obtained using a submersible spectrofluorimeter (BBE-Fluoroprobe, Germany). This in situ measuring/recording device, which can be used to perform chlorophyll $a$ analysis and integrated algal class determination, has been shown to provide a realistic estimation of the abundance and dynamics of the cyanobacterial population after specific calibration (Leboulanger et al., 2002). Zooplankton was obtained using a $212-\mu \mathrm{m}$ mesh vacuum net, during vertical sampling made from $50 \mathrm{~m}$ to the surface. The micro-crustaceans were counted from formalin fixed samples using a standard microscope (Olympus BX40) and abundances were given in number of individuals per $\mathrm{m}^{2}$.

River data come from two automatic sampling stations located in the two main tributaries, i.e., the Leysse and Sierroz, responsible for $>75 \%$ of the water flowing into the lake. Samplers (ASP station 2000 Hendress + Hauser) are located at $1.3 \mathrm{~km}$ and $0.75 \mathrm{~km}$ from the lake, for the Leysse and the Sierroz, respectively. Waters for nutrient concentrations (such as total phosphorus, $\mathrm{P}-\mathrm{PO}_{4}, \mathrm{~N}-\mathrm{NO}_{3}$ and $\mathrm{N}-\mathrm{NH}_{4}$ ) are collected using a daily time scale and have been measured since 2003 . This sampling allows obtaining an accurate estimation of the quantity of nutrient discharge into the lake as well as the key periods of such inputs.

Data such as air temperature, wind force and direction, irradiance, cloudiness, and precipitation were obtained at a 3-hour time step from the meteorological station Voglans at Chambéry airport, located less than $1 \mathrm{~km}$ from the southern shore of the lake.

\section{Results}

\subsection{Dynamics and distribution of planktothrix rubescens}

P. rubescens began to bloom in Lake Bourget in 1995/1996. Each year until 2009 (except 2004), the cyanobacterium developed significantly reaching regularly $>50 \%$ of the total phytoplankton biomass (Vinçon-Leite et al., 2002; Jacquet et al., 2005; Jacquet et al., 2014). In 2009, its cells concentration was still high, but much lower than in 2008 (a record year with 185,600 cells $/ \mathrm{mL}$ recorded in July around $15 \mathrm{~m}$ ). However, following a conjunction of factors, as explained in Jacquet et al. (2014), the cyanobacterium "disappeared" during the winter 2009/2010 (Fig. 1A). However, at the end of 2015 (i.e., OctoberNovember) and during the 2015-2016 autumn/winter period, P. rubescens reappeared (Fig. 1B, Tab. 1) and proliferated latter in the year 2016 reaching $>50,000$ cells $/ \mathrm{mL}$ in September in the metalimnion, at a depth greater than observed by past (i.e., between 20 and $25 \mathrm{~m} v s$. between 15 and $20 \mathrm{~m}$ for the period before 2009). In details, we observed at the end of October 2015 $\sim 500$ cells $/ \mathrm{mL}$ that were counted at $20 \mathrm{~m}$ and this concentration increased until mid-November to reach $\sim 2000$ cells $/ \mathrm{mL}$. Subsequently in early 2016, the cyanobacterium spread over the surface water column and remained observed along the year, reaching $>15,000$ cells $/ \mathrm{mL}$ in early summer and $\sim 50,000$ cells/ $\mathrm{mL}$ at the end of summer/early autumn. Then, a progressive decrease of the cyanobacterial biomass and a shift of $P$. rubescens cells towards the surface was recorded. Cells maintained however at a relatively high level (up to 8000 cells $/ \mathrm{mL}$ ) at all depths between surface and $50 \mathrm{~m}$ during the winter 2016/2017 (Fig. 1B). Thereafter, in 2017, P. rubescens developed massively at depth (reaching $>19,000$ cells $/ \mathrm{mL}$ by the end of May at $19 \mathrm{~m}$, $>22,000$ cells $/ \mathrm{mL}$ at $22.5 \mathrm{~m}$ on June $13,>31,000$ cells $/ \mathrm{mL}$ at $25 \mathrm{~m}$ on June 27 and $>45,000$ cells $/ \mathrm{mL}$ at $21.5 \mathrm{~m}$ on July 10 ). High concentrations ( $>25,000$ cells $/ \mathrm{mL}$ ) were measured until the end of September at various depths (Fig. 1B). During the winter 2017/2018 the cyanobacterium disappeared, and no new development of $P$. rubescens has been observed until now, i.e., 2021 (Supplementary Fig. S1a).

\subsection{Meteorological data}

Over the period 2010-2019, the time of sunshine followed approximately the same annual pattern, with an increase during summer and a decrease in winter. While the summer sunshine level was almost similar each year, some differences were, however, recorded in winter. During winters 2012/13, 2017/18 and $2018 / 19$, the daily time of sunshine stayed relatively low $(<4.0 \mathrm{~h})$ from November to March. This phenomenon was even more important for the winter 2017-18 with a very low sunshine time (maximum and average sunshine time of $2.84 \mathrm{~h}$ and $2.17 \mathrm{~h}$, respectively) and no significant fluctuation was recorded (Fig. 2A). By contrast, during winters 2015/16 and $2016 / 17$ the sunshine decreased to low values but oscillated with higher values (Fig. 2B).

\subsection{Transparency}

The transparency of the water column ranged from $1.9 \mathrm{~m}$ to $14.4 \mathrm{~m}$ between 2010 and 2019. It was higher from 2010 to 2015 compared to subsequent years. Indeed, winter peaks were recorded with a maximum depth ranging from $13.0 \mathrm{~m}$ to $14.4 \mathrm{~m}$, unlike the 2016-2019 period, where depths varied between $7.3 \mathrm{~m}$ and $10.6 \mathrm{~m}$ (Fig. 3).

\subsection{Phosphorus input from rivers}

From 2010 to 2019, the phosphorus input from the two main lake tributaries (i.e., the Leysse and Sierroz) were distributed differently. While such input was rather low from 2010 to 2012 , it increased significantly at the end of 2012 until the end of 2016. Nutrient loads were also measured to be particularly high when important river floods occurred, such as for example in 2016, June 16th (Fig. 4). During the year 2017, low inflows from the tributaries were observed, whereas the beginning of 2018 was characterised again by high inputs ( $>8.6$ tons of total-phosphorus and $>0.2$ tons of $\mathrm{P}_{-} \mathrm{PO}_{4}$ ). In 2019 , nutrient loads from the tributaries were still relatively important, especially for $\mathrm{PO}_{4}$. 


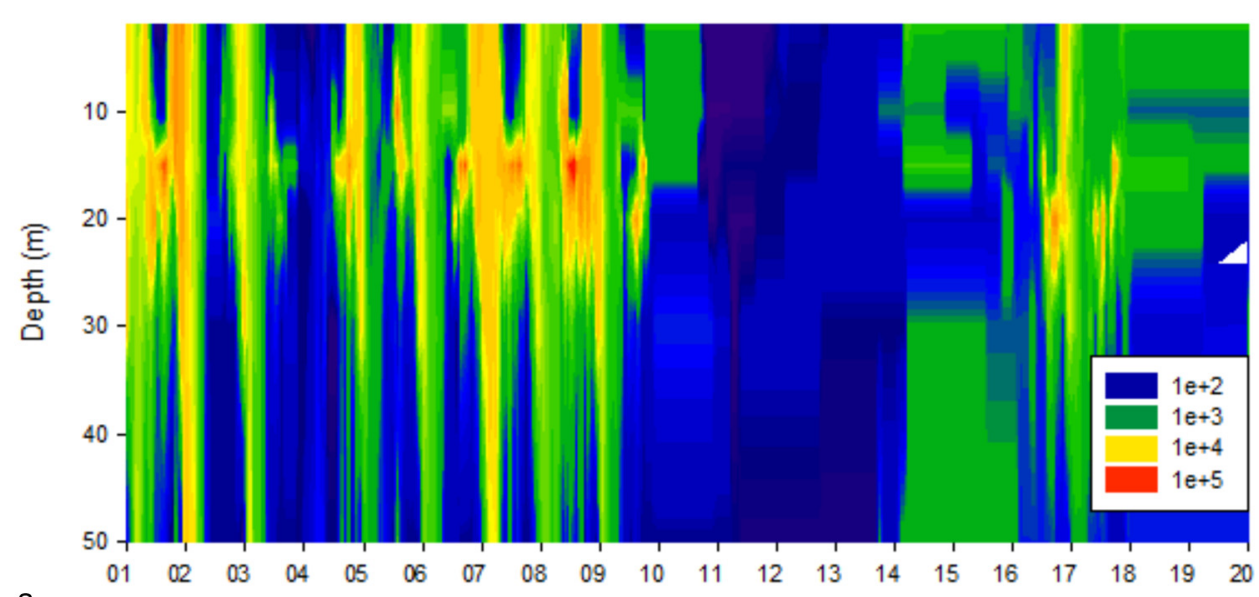

a

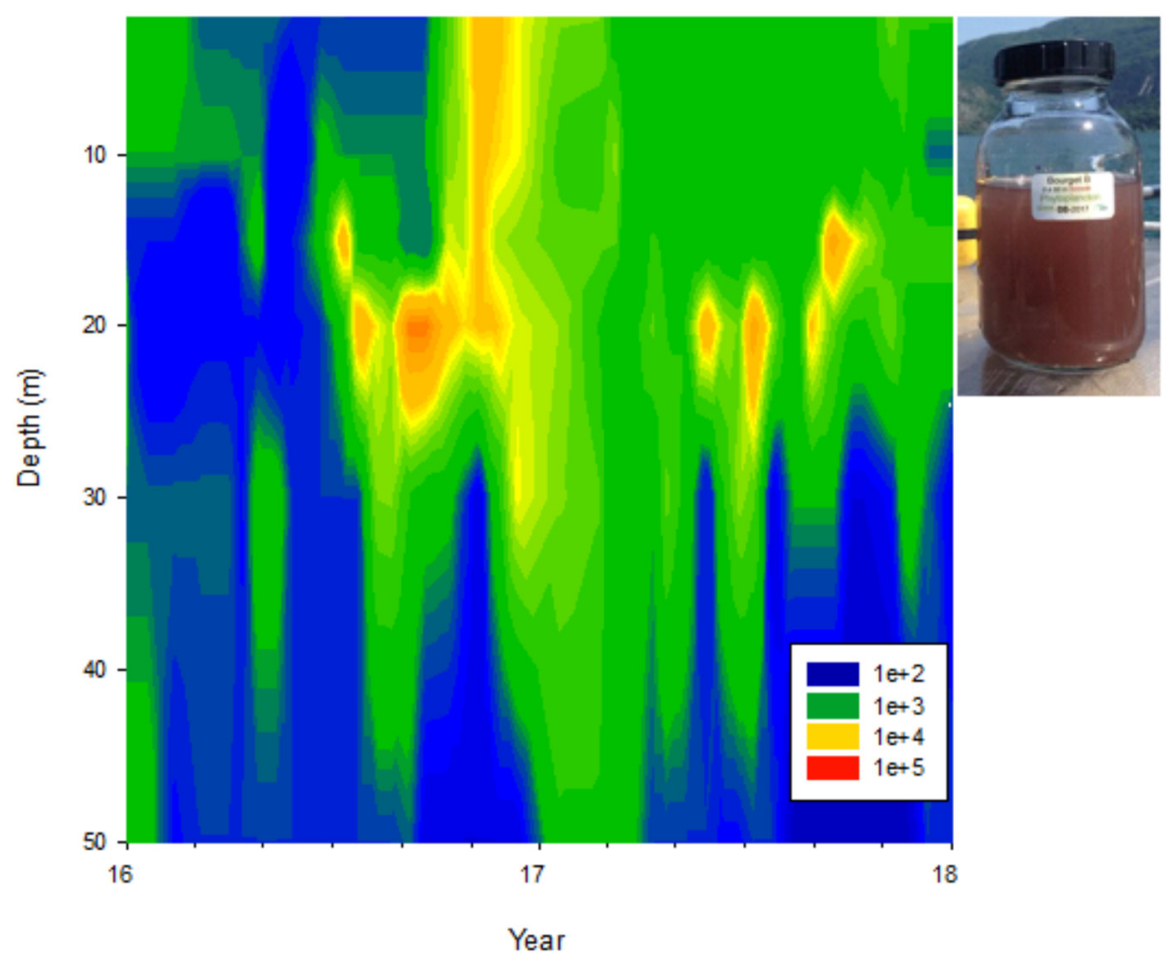

Fig. 1. (A) P. rubescens dynamics and distribution from 2001 to 2019 at point B in Lake Bourget. (B) Zoom of the 2016-2017 bloom episode associated to a picture of a $<62 \mu \mathrm{m}$ plankton net sample obtained in spring 2017.

\subsection{Phosphorus concentration}

From 2010 to 2019, both total phosphorus and orthophosphates concentrations (i.e., the mean values along the water column or in surface waters) decreased regularly. It was observed, however, an increase for the resource for the two winter periods of 2015 and 2016 (Fig. 5).

\subsection{Water column mixing and stratification}

During winter 2016, the water column was poorly homogenised, and the partial mixing occurred only from surface to $65 \mathrm{~m}$ deep. At mid-April, the maximal dissolved oxygen concentration only reached $6.3 \mathrm{mgO}_{2} / \mathrm{L}$. It is noteworthy that the reoxygenation at $140 \mathrm{~m}$ was the worst recorded for the last 10 years (not shown). During autumn 2016, the wind could blow at high speed (with gusts exceeding regularly 30 to $40 \mathrm{~km} / \mathrm{h}$, some reaching more than $100 \mathrm{~km} / \mathrm{h}$ ) and this favoured destabilization of the water column. The mixing was also partial in 2017 (despite a colder winter than in 2016) and reached at least $110 \mathrm{~m}$ deep. The maximal dissolved oxygen concentration was recorded on February 22nd with $9.2 \mathrm{mgO}_{2} / \mathrm{L}$. In 2017 , the reoxygenation at $140 \mathrm{~m}$ was better than for 2015 and 2016 but stayed significantly lower than for the years 2010 to 2013 (Fig. 6A). At the same time, the stability of the water column, from spring to autumn, was generally important (especially during the summer time). It is noteworthy, however, that mixing and thus the destratification 
M. Moiron et al.: Ann. Limnol. - Int. J. Lim. 2021, 57, 19

Table 1. Average values (from all sampled depths) calculated for each season of the cell abundance (cells $/ \mathrm{mL}$ ) of $P$. rubescens.

\begin{tabular}{|c|c|c|c|c|c|}
\hline & Winter (DJF) & Winter (JFM) & Spring (AMJ) & Summer (JAS) & Autumn (OND) \\
\hline 2002 & 12600 & 6597 & 719 & 552 & 5028 \\
\hline 2004 & 113 & 169 & 335 & 3662 & 7182 \\
\hline 2005 & 5058 & 1473 & 646 & 5259 & 4328 \\
\hline 2006 & 5796 & 4569 & 1433 & 6216 & 6624 \\
\hline 2009 & 7504 & 3212 & 1111 & 3659 & 478 \\
\hline 2010 & 32 & 0 & 0 & 4 & 15 \\
\hline 2011 & 22 & 14 & 7 & 2 & 4 \\
\hline 2012 & 12 & 21 & 0 & 0 & 19 \\
\hline 2013 & 0 & 0 & 0 & 0 & 75 \\
\hline 2018 & 129 & 10 & 17 & 0 & 0 \\
\hline 2019 & 66 & 66 & 66 & 37 & 25 \\
\hline
\end{tabular}

of the water column was relatively important at the end of 2017 (Fig. 6B) while the stability was globally higher for 2016 and 2017 compared to 2015 and 2018 (Fig. 7).

\subsection{Phyto- and zooplankton}

For the last decade, the phytoplankton biomass was higher when $P$. rubescens was recorded during the two years 2016 and 2017, more particularly during the spring season. For the zooplankton, it was usually found a more important density during the summer months (July and August). For the two years 2016 and 2017, the zooplanktonic biomass was the highest (with $>22,000 \mathrm{ind} / \mathrm{mL}$ ), especially the proportion of the herbivores (Supplementary Fig. S1b).

\section{Discussion}

Amongst aquatic microorganisms, cyanobacteria occupy an important place on Earth because of their historical and ongoing importance in ecosystem function. Moreover, many cyanobacteria are threats since that can generate toxins, especially in inland water bodies. Today, it remains very important to address key issues and highlight key items and new insights regarding these unique organisms. Typically, we still need pieces of information dealing with diversity and functional roles of cyanobacteria, harmful blooms (i.e., determinism, toxin risk, predictive models, management), molecular pathways (including toxin production), abiotic and biotic interactions with cyanobacteria, role of toxin production, as well as about the variety of applications (food supply, socio-economic models). Our study deals with the issue of harmful blooms, more particularly about the attempt to propose some scenarios (even imperfect) about the occurrence of harmful cyanobacterial blooms in lakes (e.g., Anneville et al., 2015; Gallina et al., 2017; Derot et al., 2020). This work makes sense when one knows that future climate scenarios project an increase of such proliferations both in terms of frequency and duration (Paerl and Huisman, 2009).

Blooms of $P$. rubescens have been important in Lake Bourget at different periods of the last 3 decades (Jacquet et al., 2005, 2014) and the 2016-2017 episode reminded us that such event may still occur and could impact ecosystem functioning and services (e.g., drinkable water). This study brings new insights on a variety of factors, processes and mechanisms likely to intervene and regulate the blooms of $P$. rubescens in Lake Bourget, which can be viewed and used as a successful model case of ecosystem restoration and reoligotrophication but possibly threatened by cyanobacteria. Indeed, our study highlights that toxic filamentous cyanobacteria such as $P$. rubescens can still proliferate in oligotrophic conditions, and thus not only, as most other nuisance cyanobacteria, in meso- to eutrophic conditions. We believe that this information is very important for both the scientific community and environmental mangers.

In Lake Bourget, $P$. rubescens declined after 2010 after a relatively long blooming period (from 1996 to 2009). Jacquet et al. (2014) explained that this collapse was likely due to a conjunction of factors and processes. It was suggested, among other things, that an important factor could be the existence during the autumn and/or winter period of a minimal biomass for the cyanobacterium to be able to develop during the following seasons. We tested this last information and found indeed that this autumn/winter inoculum was very important. By simply making average calculations with concentration values at each season, we found indeed that it was necessary for P. rubescens, to develop and bloom during the year, to reach a precedent autumn (OND) or winter (either DJF or JFM) 

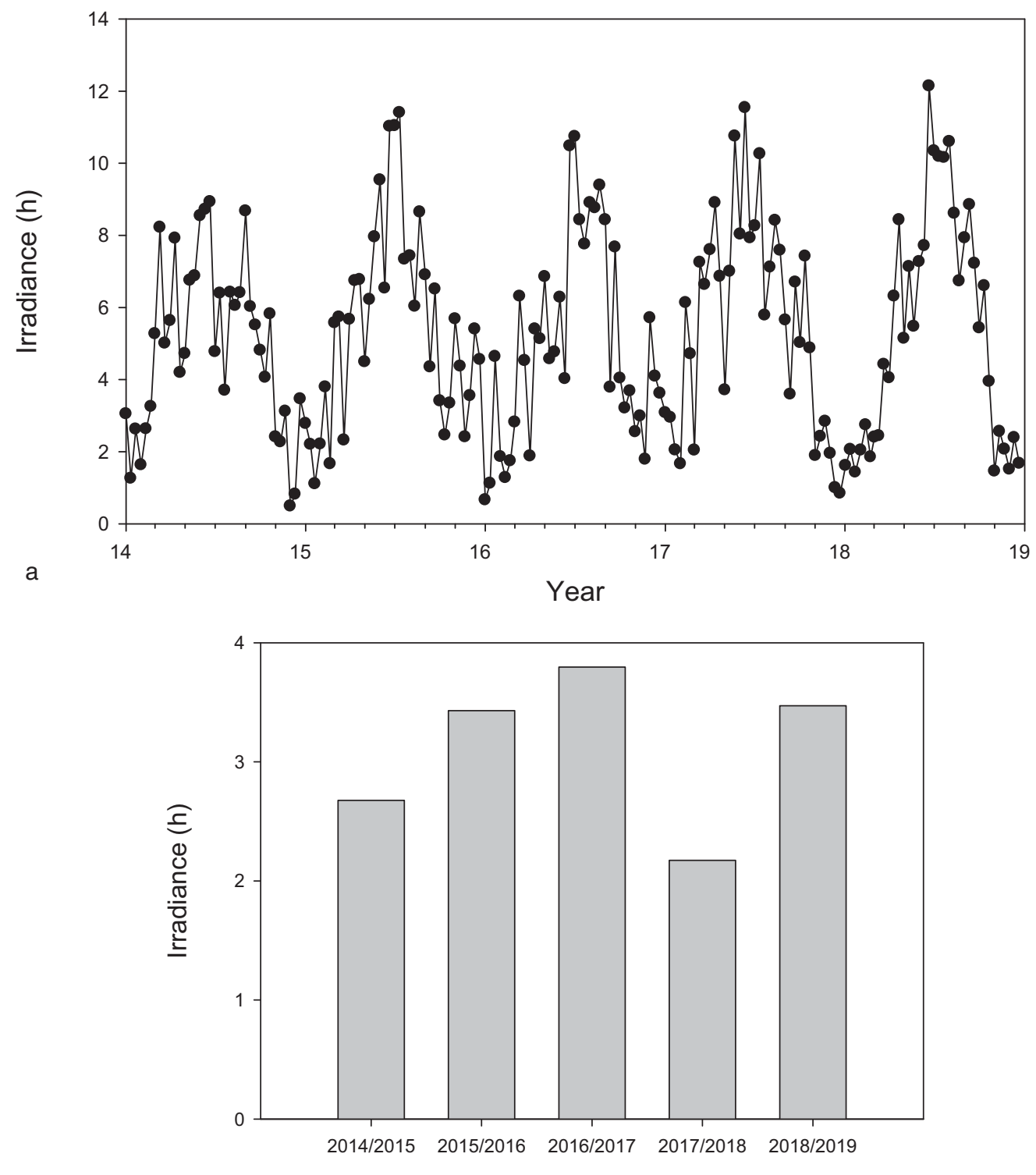

b

Winter time

Fig. 2. (A) Chronicle of sunshine time averages from January 2014 to December 2018, and (B) average of sunshine time for winters $2014-15$ to 2018-19.

Table 2. Relationships ( $r$ value) between each season for cell abundance (cells $/ \mathrm{mL}$ ) of $P$. rubescens from 2001 to 2020 ( $n=20$ ).

\begin{tabular}{llllll}
\hline & DJF & JFM & AMJ & JAS & 0.44 \\
\hline DJF & 1 & - & 0.61 & 0.51 & 0.44 \\
JFM & - & 1 & 0.75 & 0.85 & 0.51 \\
AMJ & 0.61 & 0.75 & 0.85 & 0.82 \\
JAS & 0.44 & 0.51 & 0.82 & 0.87 & 0.87 \\
OND & 0.44 & 0.51 & 1 \\
\hline
\end{tabular}

threshold above 180 cells/mL (Tab. 1). Significant positive correlations were clearly found between each season suggesting the importance of the previous months or seasons to explain subsequent blooms later during the year of
P. rubescens (Tab. 2). Thus, by sequencing the years into seasonal periods, and examining the variability in the ecological response of $P$. rubescens to environmental forcing, we show that the successions of events have considerable importance for its 


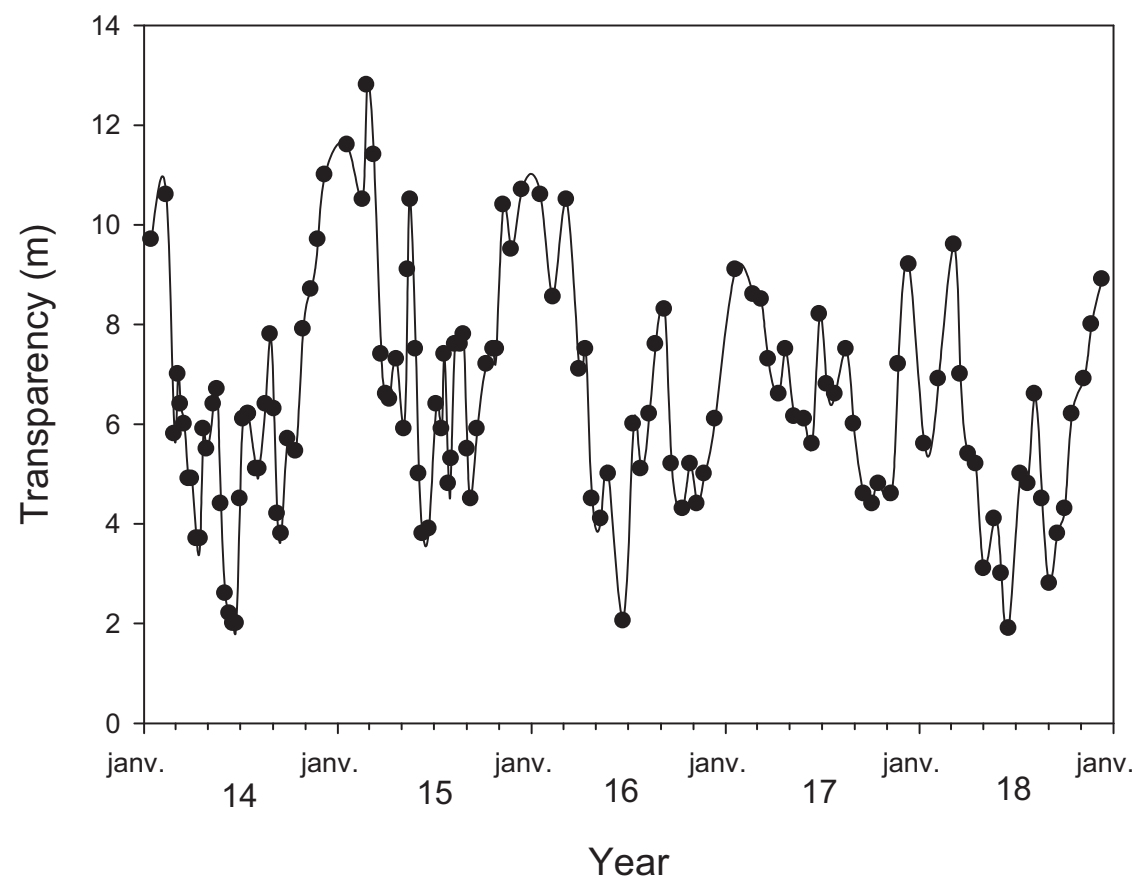

Fig. 3. Transparency evolution January 2014 to December 2018.

development or decline, provided that a minimal initial cell concentration has a determining role for $P$. rubescens dynamics in the following growth season.

After its disappearance during the 2009/2010 winter period, $P$. rubescens reappeared in the autumn of 2015. During spring 2014, partial water turnover was observed while complete winter mixing occurred annually between 2010 and 2014. In spite of adequate daylight during 2014, these conditions were not sufficient to allow the appearance of this cyanobacterium. It was only at the end of 2015 (November and December), that an inoculum was recorded, linked to favourable conditions such as significant summer inputs of nutrients from tributaries (mainly phosphorus) and a relatively high time of subsequent sunshine and mild winter. Such "warm" conditions and the absence of complete overturn may have reduced the dilution of the cyanobacterium and its growth inhibition or mortality at depth (because of light absence and gas vesicle [that intervene in its buoyancy] collapse under high pressure), not to mention the direct effect of the temperature likely to enhance cell metabolism. Incomplete winter mixing has already been reported to be favourable to the development of the cyanobacterium (e.g., Walsby et al., 1988; Jacquet et al., 2005; Posch et al., 2012). Here, we can assume that vertical and lateral transport mechanisms, induced by internal waves or upwelling events, occurred, as already demonstrated by past in Lake Bourget (Cuypers et al., 2011).

Strong inputs of total-phosphorus and $\mathrm{P}_{-} \mathrm{PO}_{4}$ in June 2016, coupled with significant sunshine during summer and a high stability of the water column, were likely the main factors leading to the important development of P. rubescens at depth where it is known to be very competitive over most eukaryotic microalgae (Dokulil and Teubner, 2012). The population ended up being the dominant species starting from summer by forming a dense layer at the metaliminion (due to its low light tolerance and stability requirement) and prevented the growth of other phytoplankters through the reduction of nutrient availability in the upper lit layers. It was in July that the bloom phase was really observed at $15 \mathrm{~m}$ depth. With an aboveaverage presence of phosphorus at this period, a high transparency, as well as a well-established stability of the water column and possibly low predation pressure until September, conditions were clearly favourable to allow this new development of $P$. rubescens.

The autumn of 2016 was characterised by a decrease in sunshine and the arrival of autumn gust of wind. Despite a general and progressive decrease in cell density, the search for light by migration was probably the reason of the rise of P. rubescens cells to the surface (Bright and Walsby, 2000). But the destabilization of the water column due to the autumn wind may have a negative impact on the presence of the cyanobacterium on the surface. Indeed, numerous wind gusts exceeding 30 to $40 \mathrm{~km} / \mathrm{h}$, some reaching more than $100 \mathrm{~km} / \mathrm{h}$, were recorded during this period.

The decrease in sunshine accompanied by a reduction in transparency, and low nutrient inputs from tributaries during the autumn/winter period of $2016 / 2017$, contributed to the decrease of the cyanobacterium, but without total disappearance. We observed that $\mathrm{P}$ could come from the bottom of the lake, because the mild winter of 2016/2017 did not allow a complete water column turnover, and hypoxic conditions at depth were clearly observed, a phenomenon likely to allow the release of phosphorus into the water column. Additionally, the sunshine stayed sufficiently high to allow $P$. rubescens to maintain and grow during the winter, since concentrations were about 2,600 cell $/ \mathrm{mL}$ on average.

Then, from spring 2017, low phosphorus and $\mathrm{P}_{-} \mathrm{PO}_{4}$ inputs from tributaries were recorded, but the partial reversal of the water column confirmed at the end of March, and phosphorus 
River Leysse
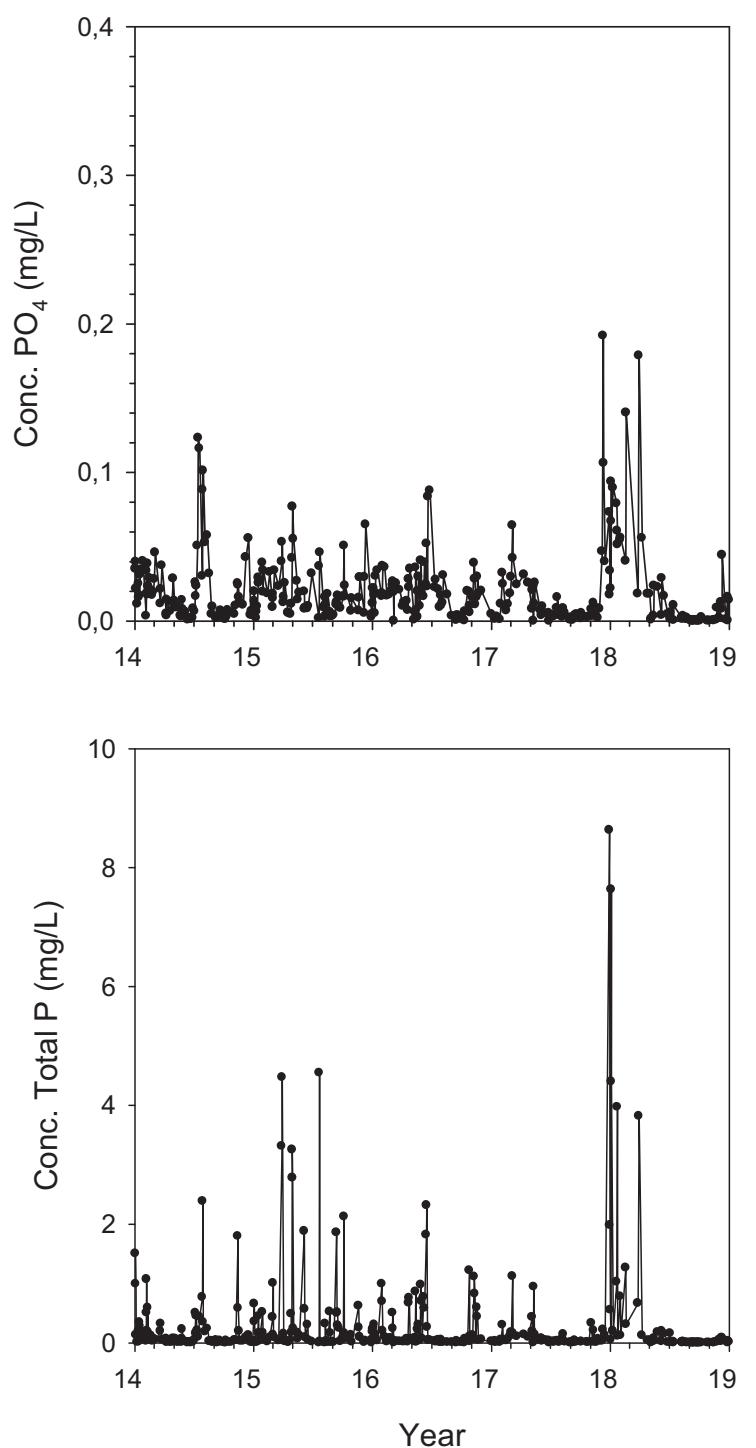

River Sierroz
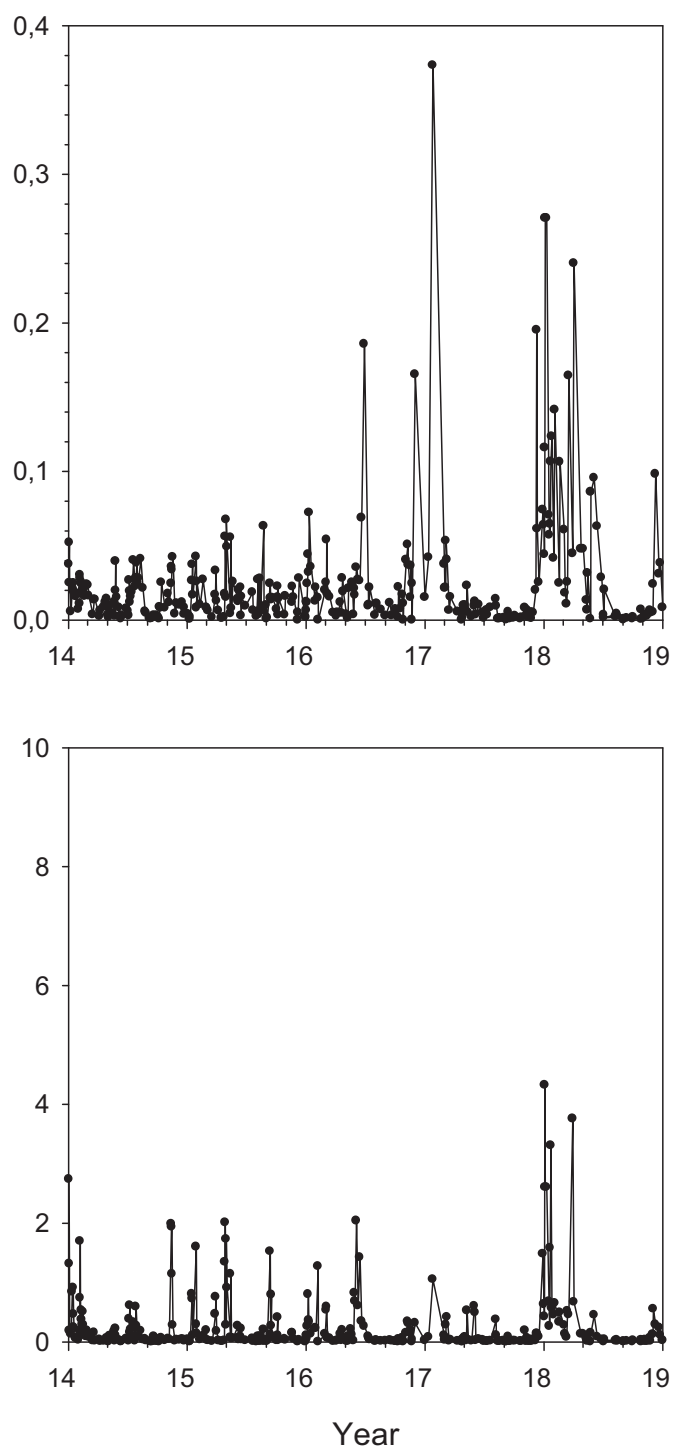

Fig. 4. Evolution of total phosphorus and $\mathrm{PO}_{4}$ input to the lake from the rivers Leysse and Sierroz from January 2014 to December 2018.

gradually moved up from deep sediments, what have compensated this lack. These favourable nutrient conditions, the return of sunshine and a transparency that was maintained at good levels during the spring/summer, allowed the winter inoculum to maintain and be the cause of a summer bloom at depth (above $20 \mathrm{~m}$ in spring and early summer) with a wellmarked presence between 15 and $30 \mathrm{~m}$. P. rubescens beginning from a relatively high concentration, the population could end up being the dominant species starting from summer by forming a dense layer in the metalimnion (due to its low light tolerance and stability requirement) and prevent the growth of other phytoplankters through the reduction of nutrient availability in the upper lit layers. Such competitive exclusion facilitated by the priority effect in which the species with higher initial concentrations outcompete the competitors (characterised by lower initial concentrations) by making the abiotic environment inhabitable has been shown elsewhere and for other species (e.g., Tapolczai et al., 2014).

From September 2017, P. rubescens was present in surface, and it was correlated with a decrease in transparency and an important decrease in the sunshine. A reduction in resources with an important water column destratification (favouring dilution of the population and collapse of intracellular gas vesicles below a critical depth) probably contributed to the "disappearance" of P. rubescens from January 2018. Despite "record" inputs from the tributaries from January to May, no reappearance occurred, likely due the absence of the inoculum. The decrease in transparency and low spring sunshine probably also contributed to the end of the cycle initiated in winter 2015. While we did not measure it directly here, predation by zooplankton could have also been important as shown by Jacquet et al. (2014) since metazoan feeders can, in 

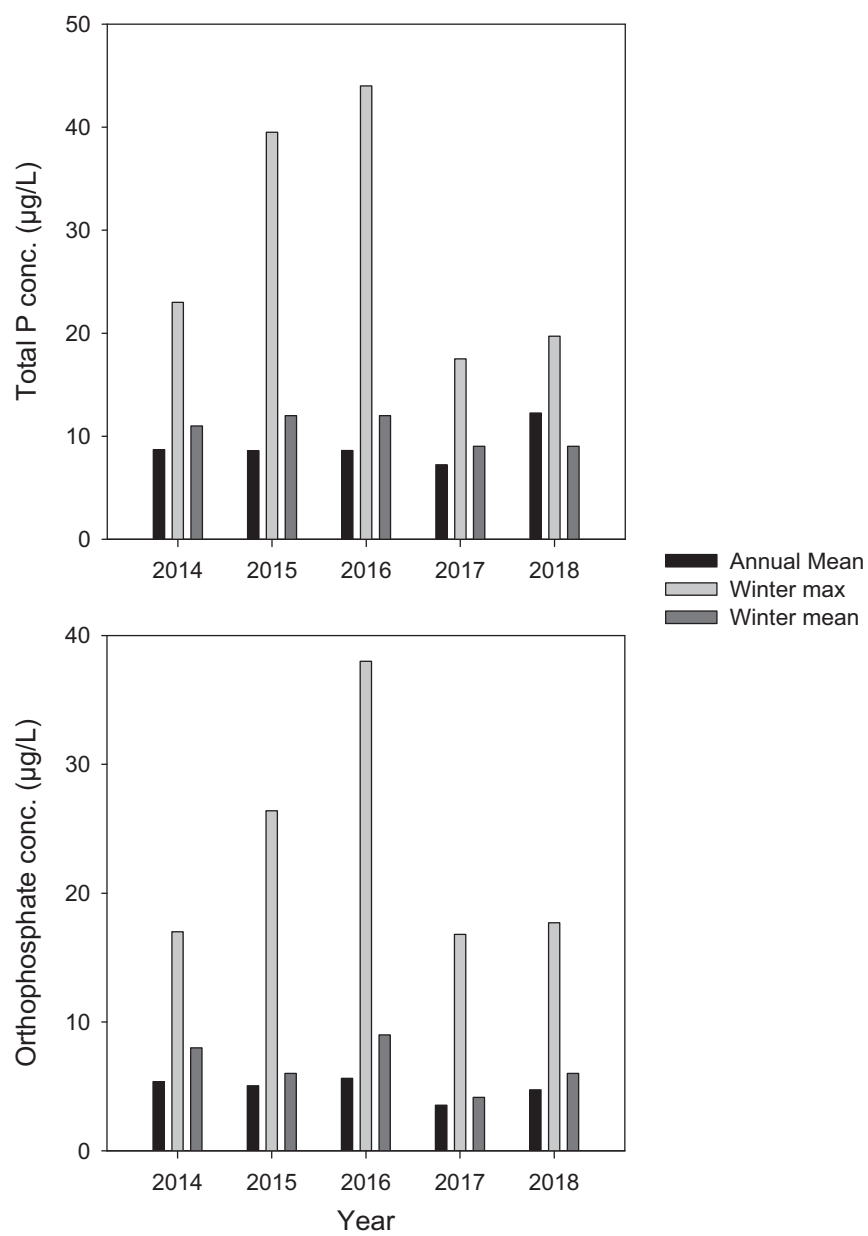

Fig. 5. Evolution of winter (max and mean values) and annual (mean value) of total phosphorus and $\mathrm{PO}_{4}$ concentrations over the water from 2014 to 2018.

some situations (i.e., low growth, size reduction, toxin absence or weak concentrations), impact $P$. rubescens significantly (Oberhaus et al., 2007; Perga et al., 2013; Jacquet et al., 2014). An increased vulnerability to parasites such as viruses or chytrids (Tao et al., 2020) could also be proposed although it remains to be tested.

After 2018, the lack of an inoculum, and a sunshine average particularly low prevented $P$. rubescens to develop again. The absence of the cyanobacterium was also confirmed in 2019 and until now (end of 2020). This agrees with previous results (Jacquet et al., 2014), highlighting again that the decline of filamentous and/or colonial cyanobacteria blooms are firstly attributed to phosphate limitation (Walve and Larsson, 2007) despite the capacity of Planktothrix to excrete alkaline phosphatases, allowing for the use of dissolved organic phosphorus when phosphate is depleted (Feuillade et al., 1990).

We are aware that when blooms reemerge, it is important to look at additional factors beyond those that previously drove the prior blooms. In multiple systems where the blooms were traditionally P-limited, anthropogenic loading of nutrients has led to eutrophication and N-limitation and $\mathrm{N}$ and $\mathrm{P}$ co-limitation arising (e.g., Barnard et al., 2021; Paerl et al., 2011, 2016; Jansson et al., 2001). However, nitrogen concentrations in the pelagic zone and river inputs did not change dramatically and did not seem to have a significant impact on the resurgence of $P$. rubescens. As already observed and discussed elsewhere (e.g., Jacquet et al., 2005; Posch et al., 2012), P. rubescens blooms went in parallel to increasing $\mathrm{NO}_{3} / \mathrm{PO}_{4}$ ratio in the surface lit layers of the lake and was probably favoured as it requires inorganic nitrogen such as $\mathrm{NO}_{3}$ and cannot fix atmospheric N2.

Finally, it is noteworthy that filamentous cyanobacteria can also produce bio-active compounds with antibacterial properties for instance so that such chemical interactions in microbial communities could also play an important role in facilitating the development of the cyanobacterium while preventing the others (Mazur-Marzec et al., 2013; Legrand et al., 2003). We conducted experiments and found indeed that allelopathic effects could be induced by extracts from $P$. rubescens on other phytoplankters (Oberhaus et al., 2008; Chiapusio et al., unpublished).

\section{Conclusion}

Beyond its role as an indicator of environmental degradation and/or major ecological changes occurring in Lake Bourget, bloom forming P. rubescens may constitute a serious threat for the lake's functioning (by inhibiting a part of the matter and energy transfer through the food webs, 

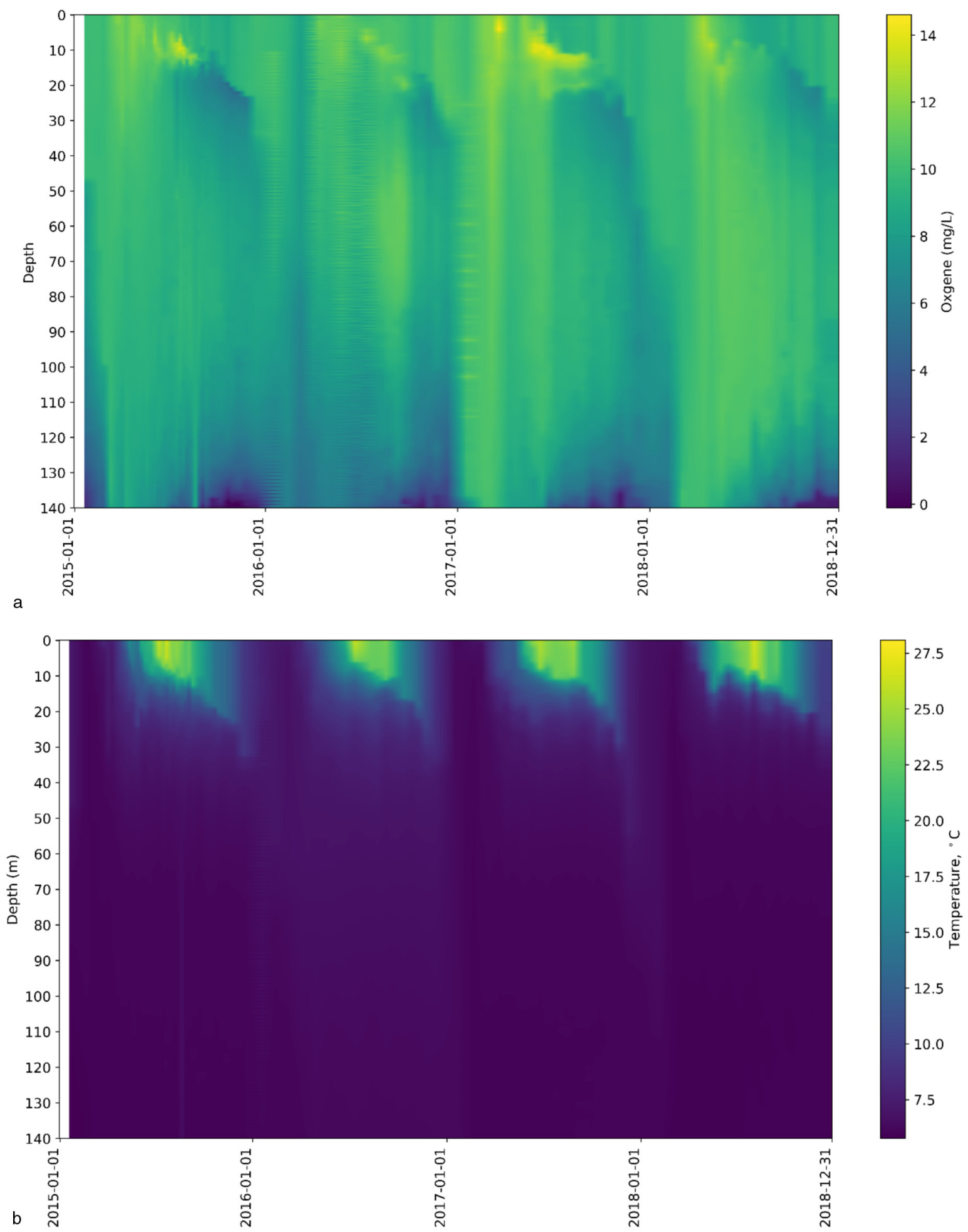

Fig. 6. Evolution of dissolved oxygen concentrations (A) and temperature (B) over the water column from 2015 to 2018.

because of chemical alterations of the water) and ecosystem services (e.g., animal kills, health hazards for humans via drinking water, consumption of fish, recreational use). $P$. rubescens is very opportunistic and can still develop and bloom following environmental shifts inducing favourable conditions for its growth and development. Our results suggest that (i) when meso- to moderately eutrophic conditions are encountered, the proliferation of $P$. rubescens remains possible (Jacquet et al., 2005; Dokulill and Teubner, 2012) and (ii) confirm that the success of $P$. rubescens can be attributed to 


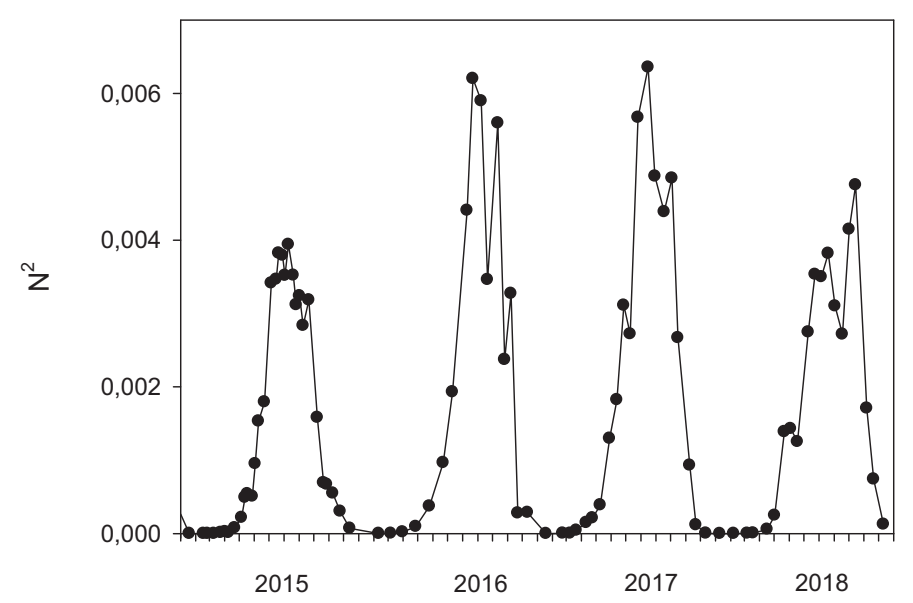

Fig. 7. Evolution of the Brunt-Väisälä frequency $N^{2}$ from 2015 to 2018.

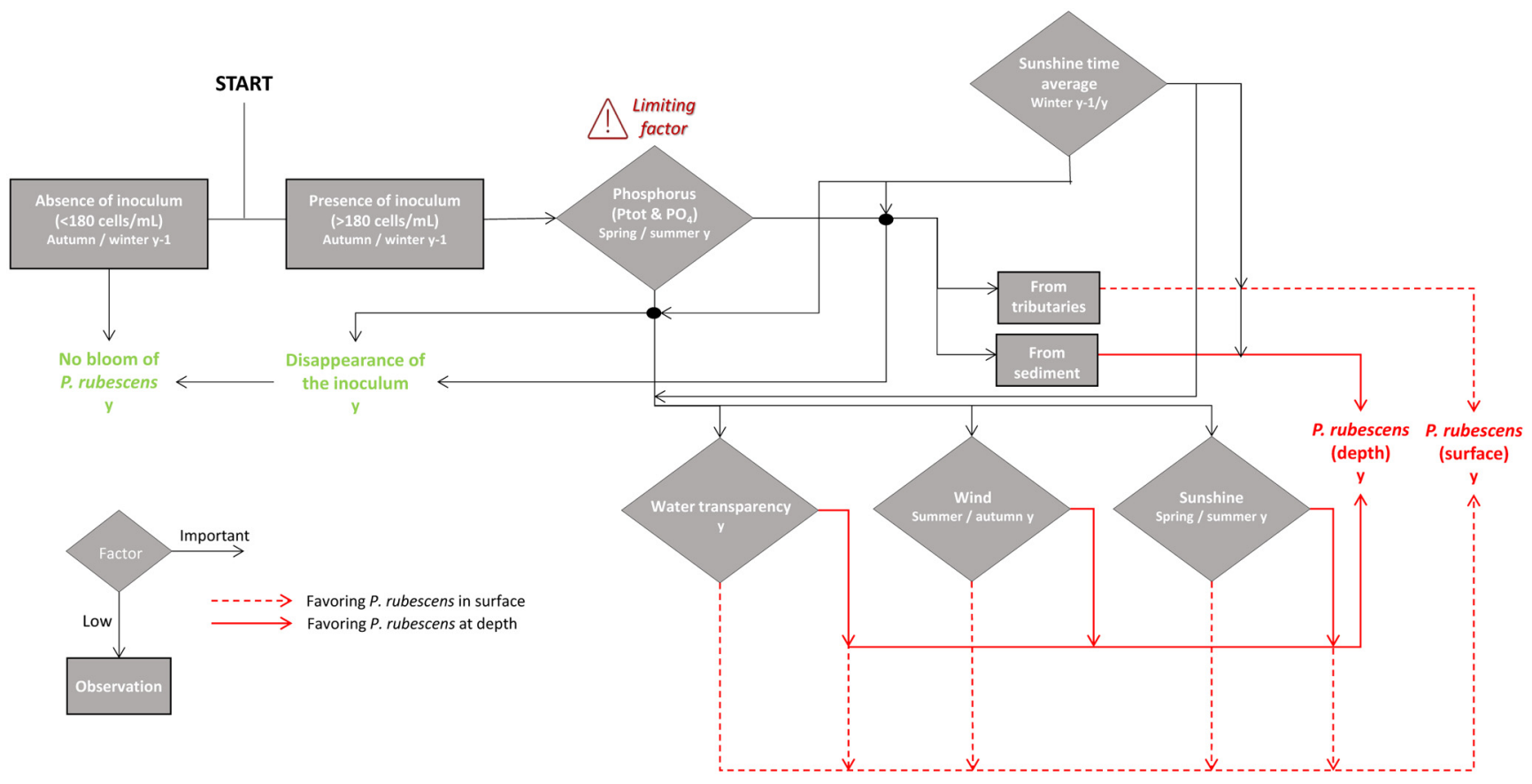

Fig. 8. P. rubescens is likely to bloom in Lake Bourget following a conjunction of factors and processes. Firstly, the presence of an autumn/ winter innoculum of the cyanobacterium the year before is significant. Secondly, the phosphorus resource remains a key issue and severe limitation in winter/spring of the year can prevent the bloom whereas presence or input (i.e., $\mathrm{P}$ already present in surface waters of the lake or coming from tributaries or from the sediment) during the winter/spring of the year can be crucial. Moreover, a relatively high level of winter irradiance and/or water transparency may clearly favor the initial development of P. rubescens merely at depth (i.e., between 15 and $25 \mathrm{~m}$ ).

a combination of physico-chemical factors and ecological processes (e.g., Jacquet et al., 2005, 2014; Posch et al., 2012). This study merely suggests that future environmental conditions (extreme events and runoff, temperature increase, deoxygenation and $\mathrm{P}$ release from the bottom) may potentially provide conditions for the development and bloom of the cyanobacterium in Lake Bourget, while the latter is oligotrophic. Associated to the counting of a threshold of filaments during the autumn/winter period the year before the bloom (e.g., $>180$ cells $/ \mathrm{mL}$ ) and relatively warm winter conditions known to be an important trigger to serve at maintaining the population at a level where it will be possible to proliferate (e.g., Jacquet et al., 2014; Anneville et al., 2015; Gallina et al., 2017; Kerimoglu et al., 2017), a simple alert can be imagined and is proposed in Figure 8. This study may allow for predictions in a variety of lakes on how P. rubescens dynamics could develop in times of climate change and respond to inter-annual weather conditions. However, important questions remain: Where did the inoculum come from? Are lateral transport mechanisms induced for instance by internal waves and upwelling events, which occur frequently in Lake Bourget (Cuypers et al., 2011), important drivers for 
population development? Were filaments present but not detected because of methodical bias due to sampling, sample preparation and/or counting? Or were these filaments located somewhere else in the lake? Etc. In the future, to be able to predict a potential new development of $P$. rubescens, it could be useful to propose a 3D model of the dynamics and distribution of this cyanobacterium, in relation to different factors, themselves linked to the growth of this such particular species.

\section{Conflict of interest}

Authors declare no conflict of interest.

Acknowledgements. We are grateful to the technicians who make possible to obtain a large amount of data of high quality (C) OLA-IS, AnaEE-France, INRAE of Thonon-les-Bains, CISALB [Rimet et al. https://doi.org/10.4081/jlim nol.2020.1944]) and Orlane Anneville for her critical reading of a former version of this article. Professor Steven Wilhelm is greatly acknowledged for improving a former version of this manuscript and English editing.

\section{Supplementary Material}

Supplementary Fig. S1. Evolution of the phytoplanktonic biomass (a) using the main classes and the (b) zooplankton using the proportion of the total microcrustacean zooplankton, herbivores and herbivore cladocerans and between 2004 and 2019. A zoom is also proposed for years 2015 to 2018 for the herbivores at the different season.

The Supplementary Material is available at https://doi.org/ 10.1051/limn/2021014.

\section{References}

AFNOR EN 15204. 2006. Water quality - Guidance standard on the enumeration of phytoplankton using inverted microscopy (Utermöhl technique). Afnor 1-39.

AFNOR. 2015. Qualité de l'eau. Recueil des normes. ISBN: 978-2-12-3179311-5

Anagnostidis K, Komarek J. 1988. Modern approach to the classification system of cyanophytes. 3-Oscillatoriales. Arch Hydrobiol 80: 327-472.

Anneville A, Domaizon I, Kerimoglu O, Rimet F, Jacquet S. 2015. Blue-Green Algae in a "Greenhouse Century"? New insights from field data on climate change impacts on Cyanobacteria abundance. Ecosystems 18: 441-458.

Barnard MA, Chaffin JD, Plaas HE, et al. 2021. Roles of nutrient limitation on western Lake Erie CyanoHAB toxin production. Toxins 13: 47.

Bright DI, Walsby AE. 2000. The daily integral of growth by Planktothrix rubescens calculated from growth rate in culture and irradiance in Lake Zurich. New Phytolog 146: 301-316.

Briand J-F, Jacquet S, Flinois C, et al. 2005. Variations in the microcystins production of Planktothrix rubescens (cyanobacteria) assessed by a four-years in situ survey of Lac du Bourget (France) and by laboratory experiments. Microb Ecol 50: 418-428.

Capo E, Debroas D, Arnaud F, et al. 2016. Long-term dynamics in microbial eukaryotes communities: a palaeolimnological view based on sedimentary DNA. Molec Ecol 25: 5925-5943.
Capo E, Debroas D, Arnaud F, Perga ME, Chardon C, Domaizon I. 2017. Tracking a century of changes in microbial eukaryotic diversity in lakes driven by nutrient enrichment and climate warming. Environ Microbiol 19: 2873-2892.

Cuypers Y, Vinçon-Leite B, Groleau A., Tassin B, Humbert J-F. 2011. Impact of internal waves on the spatial distribution of Planktothrix rubescens (cyanobacteria) in an alpine lake. ISME J 5: 580-589.

Derot J, Yajima H, Jacquet S. 2020. Advances in forecasting harmful algal blooms using machine learning models: A case study with Planktothrix rubescens in Lake Geneva. Harmful Algae 99: 101906.

Dokulil MT, Teubner K. 2012. Deep living Planktothrix rubescens modulated by environmental constraints and climate forcing. Hydrobiologia 698: 29-46.

Ernst B, Hoeger SJ, O'Brien E, Dietrich DR. 2009. Abundance and toxicicty of Planktothrix rubescens in the pre-alpine Lake Ammersee, Germany. Harmful Algae 82: 329-342.

Fastner J, Erhard M, Carmichael WW, et al. 1999. Characterization and diversity of microcystins in natural blooms and strains of the genera Microcystis and Planktothrix from German freshwaters. Arch Hydrobiol 145: 147-163.

Feuillade J. 1994. The cyanobacterium (blue-green algae) Oscillatoria rubescens D.C. Arch Hydrobiol Beih Eregbn Limnol 41: 77-93.

Feuillade M, Feuillade J, Blanc P. 1990. Alkaline phosphatase activity fluctuations and associated factors in a eutrophic lake dominated by Oscillatoria rubescens. Hydrobiology 207: 233-240.

Frossard V, Grandrémy N, Arthaud F, Guillard J, Jacquet S. Evidence of ecological shifts in fresh water ecosystems: A case study with Lake Bourget (France).

Gallina N, Beniston M, Jacquet S. 2017. Estimating future cyanobacterial occurrence and importance in lakes: a case study with Planktothrix rubescens in Lake Geneva. Aquat Sci 79: 249-263.

Jacquet S, Briand J-F, Leboulanger C, et al. 2005. The proliferation of the toxic cyanobacterium Planktothrix rubescens following restoration of the largest natural French lake (Lac du Bourget). Harmful Algae 4: 651-672.

Jacquet S, Kerimoglu O, Rimet F, Paolini G, Anneville O. 2014. Cyanobacterial bloom termination: the disappearance of Planktothrix rubescens from Lake Bourget after restoration. Freshw Biol 59: 2472-2489.

Jacquet S, Arthaud F, Barbet D, et al. 2017. Suivi environnemental des eaux du lac du Bourget pour l'année 2016. Rapport INRACISALB-CALB, 211 pages.

Jansson M, Bergstrom AK, Drakare S, Blomqvist P. 2001. Nutrient limitation of bacterioplankton and phytoplankton in humic lakes in northern Sweden. Freshw Biol 46: 653-666.

Jenny JP, et al. 2020. Scientists' Warning to Humanity: Rapid degradation of the world's large lakes. J Great Lakes Res 46: 686-702.

Kerimoglu O, Jacquet S, Vinçon-Leite B, et al. 2017. Modelling the plankton groups of the deep, peri-alpine Lake Bourget. Ecol Model 359: 415-433.

Kurmayer R, Blom JF, Deng L, Pernthaler J. 2015. Integrating phylogeny, geographic niche partitioning and secondary metabolite synthesis in bloom-forming Planktothrix. Isme $J$ 9: 909-921.

Leboulanger C, Dorigo U, Jacquet S, LeBerre B, Paolini G, Humbert J-F. 2002. Application of a submersible spectrofluorometer for rapid monitoring of freshwater cyanobacterial blooms: a case study. Aquat Microb Ecol 30: 83-89. 
Legrand C, Rengefors K, Fistarol GO, Granéli E. 2003. Allelopathy in phytoplankton - biochemical, ecological and evolutionary aspects. Phycologia 42: 406-419.

Mazur-Marzec H, et al. 2013. Occurrence of cyanobacteria and cyanotoxins in the Southern Baltic Proper. Filamentous cyanobacteria vs. single-celled picocyanobacteria. Hydrobiologia 701: 235-252.

Micheletti S, Schanz F, Walsby AE. 1998. The daily integral of photosynthesis by Planktothrix rubescens during summer stratification and autumnal mixing in Lake Zürich. New Phytolog 138: 233-249.

Oberhaus L, Gelinas M, Pinel-Alloul B, Ghadouani A, Humbert J-F. 2007. Grazing of tow toxic Planktothrix species by Daphnia pulicaria: potential for bloom control and toxin transfer of microcystins. J Plankton Res 29: 827-838.

Oberhaus L, Briand J-F, Humbert J-F. 2008. Allelopathic growth inhibition by the toxic, bloom-forming cyanobacterium Planktothrix rubescens. FEMS Microbiol Ecol 66: 243-249.

Paerl HW, Huisman J. 2009. Climate change: a catalyst for global expansion of harmful cyanobacterial blooms. Environ Microbiol Rep 1: 27-37.

Paerl HW, Xu H, McCarthy MJ, et al. 2011. Controlling harmful cyanobacterial blooms in a hyper-eutrophic lake (Lake Taihu, China): the need for a dual nutrient (N \& P) management strategy. Water Res 45: 1973-1983.

Paerl HW, Scott JT, McCarthy MJ, et al. 2016. It takes two to tango: When and where dual nutrient $(\mathrm{N} \& \mathrm{P})$ reductions are needed to protect lakes and downstream ecosystems. Environ Sci Technol 50: 10805-10813.

Pelletier JP, Orand A. 1978. Appareil de prélèvement d'un échantillon dans un fluide. Brevet d'invention 76.08579.

Perga ME, Domaizon I, Guillard J, Hamelet V, Anneville O. 2013. Are cyanobacterial blooms trophic dead ends? Oecologia 172: 551-562.

Posch T, Koster O, Salcher MM, Pernthaler J. 2012. Harmful filamentous cyanobacteria favoured by reduced water turnover with lake warming. Nature Clim Change 2: 809-813.

Reynolds C, Huszar V, Kruk C, Naselli-Flores L, Melo S. 2002. Towards a functional classification of the freshwater phytoplankton. J Plankton Res 24: 417-428.
Rimet F, et al. 2020. The Observatory on LAkes (OLA) database: Sixty years of environmental data accessible to the public. J Limnol DOI: 10.4081/jlimnol.2020.1944.

Rimet F, Druart J-C. 2018. A trait database for phytoplankton of temperate lakes. Ann Limnolog 54: 18.

Savichtcheva O, Debroas D, Perga ME, et al. 2015. Effects of nutrients and warming on Planktothrix dynamics and diversity: a palaeolimnological view based on sedimentary DNA and RNA. Freshw Biol 60: 31-49.

Sotton B, Anneville O, Cadel-Six S, Domaizon I, Krys S, Guillard J. 2011. Spatial match between Planktothrix rubescens and whitefish in a mesotrophic peri-alpine lake: evidence of toxins accumulation. Harmful Algae 10: 749-758.

Sotton B, Guillard J, Bony S, et al. 2012. Impact of toxic cyanobacterial blooms on Eurasian perch (Perca fluviatilis): experimental approaches and in situ observations in a peri-alpine lake. PLoS ONE 7: e52243.

Strickland JDH, Parsons TR. 1972. A practical handbook of seawater analysis. 2nd Ed. Bull. Fish. Res. Bd. Canada 167: 311.

Tao Y, Wolinska J, Hölker F, Agha R. 2020. Light intensity and spectral distribution affect chytrid infection of cyanobacteria via modulation of host fitness. Parasitology 147: 1206-1215.

Tapolczai K, Anneville O, Padisak J, et al. 2014. Occurrence and mass development of Mougeotia spp. (Zygnemataceae) in large, deep lakes. Hydrobiologia 745: 17-29.

Uthermöhl H. 1958. Zur Vervollkommung der quantitativen phytoplankton-methodik. Mitt Int Ver Limnol 9: 38.

Vinçon-Leite B, Tassin B, Druart J-C. 2002. Phytoplankton variability in Lake Bourget: Phytoplankton dynamics and meteorology. Lakes \& Reservoirs: Research and Management 7: 93-102.

Walsby AE, Avery A, Schanz F. 1988. The critical pressure of gas vesicles in Plantktothrix rubescens in relation to the depth of winter mixing in lake Zurich, Switzerland. Journal of Plankton Research 20: $1357-1375$.

Walve J, Larsson U. 2007. Blooms of Baltic Sea Aphanizomenon sp. (Cyanobacteria) collapse after internal phosphorus depletion. Aquatic Microbial Ecology 49: 57-69.

Zotina T, Koster O, Juttner F. 2003. Photoheterotrophy and lightdependent uptake of inorganic and organic nitrogenous compounds by Planktothrix rubescens under low irradiance. Freshwater Biology 48: 1859-1872.

Cite this article as: Moiron M, Rimet F, Girel C, Jacquet S. 2021. Die hard in Lake Bourget! The case of Planktothrix rubescens reborn. Ann. Limnol. - Int. J. Lim. 57: 19 